\title{
THE AUTHORITY OF LOCAL GOVERNMENTS IN PREVENTING AND ERADICATION OF FOREST DESTRUCTION
}

\author{
Fatah Hidayat ${ }^{1}$, Cholidah Utama ${ }^{2}$
}

\begin{abstract}
Forest damage in Indonesia has been increasing from year to year, both forest damage caused by illegal logging, forest burning, mining without permits, and plantations without permits have caused state losses, damage to socio-cultural life and the environment, as well as increasing global warming which has become national, regional and international issues. Forest damage caused by forest fires carried out by the community both for clearing agricultural land and for plantation land, burning forests and land seems to never stop threatening the lives of people in Indonesia because most Indonesian people become farmers, especially those in the regions. who must clear forests for agricultural land. This is because local governments have the authority to regulate and limit the permits of companies operating in the forestry, plantation and mining sectors in their respective areas. Therefore, local governments must make policies and make concrete mitigation in terms of preventing and eradicating forest destruction that occurs in each region.
\end{abstract}

Keywords: Authority, Local Government, and Forest Destruction.

\section{The Introduction}

The forest damage caused by illegal logging, forest burning, mining without permits, and plantations without permits has caused losses to the state, damages socio-cultural life and the environment, and increases global warming which has become a national, regional and international issue. That forest destruction has become a crime with extraordinary, organized and transnational impacts carried out with a sophisticated modus operandi, has threatened the survival of the community so that in order to prevent and eradicate forest destruction effectively and to provide a deterrent effect, a strong and reliable legal foundation is needed. able to guarantee the effectiveness of law enforcement. Based on data from Forest Watch Indonesia-Global Forest Watch, it is clear that Indonesia is experiencing the fastest loss of tropical forests in the world. (Achmaliadi, 2005, p. 27).

Forests in Indonesia have been severely damaged, that is the big problem the government must face today. Forest damage caused by forest burning by the community, both for clearing agricultural land and for plantation land. Burning forests and land seems to never stop threatening the lives of people in Indonesia. With this fact, encouraging various groups to highlight the policies made by the government in the forestry sector. In fact, preventing forest destruction is one of the focus problems highlighted by various groups, both government and society. Nevertheless, questions remain whether the regulations in the forestry sector are in accordance with the

1 Fakultas Syariah dan Hukum UIN Raden Fatah Palembang, Email: fatahhidayat_uin@radenfatah.ac.id

2 Fakultas Syariah dan Hukum UIN Raden Fatah Palembang, Email: cholidahutama_uin@radenfatah.ac.id 
spirit of reform and awareness of the implementation of sustainable development or not. (Bram, 2014, p. 58).

Forest destruction is an environmental problem for humans, which can be seen from the point of view of decreasing forest quality. Forest quality concerns environmental values for human health, welfare and security. Environmental values for various forms of use. The loss and reduction of environmental values due to certain uses by mankind. According to Druptsteen, environmental problems are the deterioration of environmental quality. Or in other words, that the problem of forest destruction which is related to environmental disturbance between humans and the environment takes the form of pollution, depletion, and forest / environmental destruction. (Hamzah, 2005, p. 7-8).

The responsibility for preventing forest destruction rests with the government, both central and local governments, in the sense that they do not leave it to individuals or become civil law. The responsibility for environmental management rests with the government which has consequences for the institution and authority for the government to carry out environmental management in terms of preventing forest destruction. In law, environmental management becomes part of administrative law. Thus, it is hoped that environmental management will be carried out by paying attention to the existing ecosystems in the environment. (Muhjad, 2015, p. 5).

Although there is already a law on spatial planning which regulates the division of authority and responsibility between the central government, provincial governments, and district / city governments in managing forest areas, namely Law Number 26 of 2007 concerning Spatial Planning, in reality it has not be the best solution to problems that often arise related to forest management (Jauchar, 2012: 19). Based on the description above, that the destruction of forests in Indonesia is getting worse day by day, such as floods in Indonesia that cannot be avoided and even becomes a subscription every year. In fact, the government has made Law Number 23 of 2014 concerning Regional Government which gives regional governments the authority to protect the forests in their respective regions. Then the government has issued Law Number 18 of 2013 concerning the Prevention and Eradication of Forest Destruction. Thus the authors are interested in researching it, with the title "The Authority of Local Governments in Doing Prevention and Eradication of Forest Destruction". With the formulation of the problem regarding how the authority of the regional government in protecting and maintaining forests in their respective regions according to Law Number 23 of 2014 as revised by Law Number 9 of 2015 concerning Regional Government. Then regarding how the government's efforts to prevent and eradicate forest destruction in its area according to Law Number 18 of 2013 concerning Prevention and Eradication of Forest Destruction.

\section{Research Methods}

While the research method used is normative legal research, meaning that this research is library research to analyze "Local Government Authorities in Preventing and Combating Forest Destruction". While the research materials use legal materials obtained from the results of library research. While the approach of this research is to use a philosophical approach and a statutory approach related to the problems in this research. 


\section{Discussion and Results}

\section{The Authority of Local Governments in Protecting and Maintaining Forests in Their Respective Areas}

The regional government has the authority to regulate and manage government affairs by itself according to the principles of autonomy and assistance tasks. Local government includes the Governor, Regent or Mayor and regional apparatuses as elements of regional government administration. In this regard, the role of the regional government is everything that is done in the form of good actions in the context of implementing regional autonomy as a right, authority and obligation of the regional government to regulate and manage government affairs and the interests of the local community in accordance with statutory regulations.

The idea of autonomy is getting more and more attention and has become a topic of interest. This is further strengthened by the many demands that have come from regions that want their territories to receive autonomous rights. The shift from the centralized system to decentralization is said to be a return of central power to the regions (Sarundajang, 1999, p. 2). In the implementation of regional autonomy, regions have rights in the form of regulating and managing their own domestic affairs (government), electing regional leaders, managing regional apparatus, managing regional wealth, regulating regional taxes and regional levies, obtaining profit sharing from natural resource management and other resources that are in the area, get sources of income in the region, and get other rights that are regulated in legislation (Wiyono, 2007, p. 23).

Then Law Number 22 of 1999 was born as revised by Law Number 32 of 2004 as revised by Law Number 23 of 2014 as revised by Law Number 9 of 2015 concerning Regional Government jolting all parts of Indonesia. Like a water faucet that has just been opened, the echoes of Regional Autonomy penetrate all regions. No exception a small but densely populated city. All regions seem to be competing in managing their territories. Whether it's the arrangement of Regional Original Income or the Internal Management (Nurdiansyah, 2005, p. 34).

With the existence of regional autonomy, the problem is not limited to the handover of power, but the readiness and capability of the regions given the authority are important points of the success or failure of the implementation of regional autonomy in Indonesia. Because regions that have autonomous rights, this means that they are required to be independent, which of course for regions that are not ready for regional autonomy not only have to carry out a tough task but also have to be clever in coping with all existing problems so that they are able to be independent. If not, it is possible that they will collapse because they are unable to realize the objectives of the implementation of regional autonomy.

The implementation of regional autonomy, which was launched in January 2001, has brought about political changes at the local (regional) level. One of them is the strengthening of the role of the Regional People's Representative Council. If in the previous period the Regional People's Representative Council was only a rubber stamp and its position was under the legislature, after regional autonomy, the role of the legislature became 
bigger, it could even dismiss the regional head. The implementation of regional autonomy and its consequences deserves close attention. Not only does regional autonomy transfer the potential for corruption from Jakarta to the regions, regional autonomy also creates petty kings who nourish corruption, collusion and nepotism. In addition, with the existence of regional autonomy, the arrogance of the Regional People's Representative Council is getting out of control because they are representatives of influential local elites. Because of its role, in the midst of an atmosphere of democracy that has not yet been developed at the local level, the Regional People's Representative Council will become a new political force that is very vulnerable to corruption. Whereas the aim of granting the widest possible autonomy to the regions is directed at accelerating the realization of community welfare through improved services, empowerment, and community participation. In addition, through broad autonomy, in a strategic globalization environment, regions are expected to be able to increase competitiveness by taking into account the principles of democracy, equity, justice, privileges and specialties as well as the potential and diversity of Regions in the system of the Unitary State of the Republic of Indonesia.

In order to achieve the goals of regional autonomy, in Law Number 23 of 2014 as revised by Law Number 9 of 2015 concerning Regional Government, in order to achieve the goals of regional autonomy in order to increase competitiveness by taking into account the principles of democracy, equity, justice, privileges and specificities as well as potential and regional diversity in the system of the Unitary State of the Republic of Indonesia. So changes to the organizational structure of the regional apparatus in the Regency / City Regional Government are inevitable. Likewise with the Provincial Government. Although it did not change the organizational structure of the regional apparatus, the additional authority had an impact on changing the tasks and functions of the regional apparatus organizations under it. The movement of these regional apparatus organizational organizations has an impact on the mobilization of human resources, facilities and infrastructure as well as funding. This is what is quite troublesome for local governments. Law Number 23 of 2014 as revised by Law Number 9 of 2015 concerning Regional Government, provides an order that the mobilization of these resources must have been completed no later than 2 (two) years from the time it was promulgated.

The criteria for authority between the central, provincial and district / city governments can be seen in the table below: 
Table I: Criteria for Authority Between Central, Provincial and Regency I City Governments Central Government
1. The location is cross ${ }^{-}$ provincial or cross- $^{-}$ country;
2. The users are cross- provincial or cross- $^{-}$ country;
3. Benefits or negative impacts across provinces or across countries; Province Government
1. The location is across districts / cities;
2. The users are cross regency / municipal regions;
3. Benefits or negative impacts across districts / cities; and / or

\section{Regency/City Government}
1. The location is in the regency / city;
2. The user is in a regency / city area;
3. The benefits or negative impacts are only in the regency / city area; and / or
4. The use of its resources is more efficient if it is carried out by regencies / cities.

4. The use of its resources is more efficient when it is carried out by the Central

4. The use of its resources is more efficient if it is carried out by the Provincial Region.

Government; and / or;

5. Its role is strategic for the national interest.

Source: http://www.depkes.go.id, Depdagri, diakses tanggal 12 April 2020.

Based on the table above, regarding the authority of the central government, provincial government and district / city government, it is clear about the benefits and negative impacts of the respective authorities of the central, provincial and district / city governments.

Table II: Criteria for Authority between Central Government and Local Government

Central Government
1. Establish Standard Procedures
and Criteria Norms, no later than
2 (two) years from the
promulgation of government
regulations regarding the
implementation of concurrent
government affairs and carry out
guidance and supervision.;
2. Cancel regional policies that are
not guided by the Norms of
Strategy, Procedures and
Criteria;

3. Setting Minimum Service Standards.

1. Establish Regional policies to carry out Government Affairs which become the authority of the Regions based on the Norms of Standard Procedures and Criteria;

2. Within a period of 2 (two) years, the Central Government has not established Standard Procedure and Criteria Norms, the Regional Government carries out Government affairs which become the regional authority;

3. Prioritizing the implementation of Mandatory Government Affairs related to Basic Services based on Minimum Service Standards. As explained in the preamble section of Law Number 9 of 2015 concerning Regional Government with the aim of ensuring development and services to the community.

Source: http://www.depkes.go.id, Depdagri, diakses tanggal 12 April 2020. 
Based on the table above, regarding the authority of the central government and local governments, it is clear that the Standard Procedure and Criteria Norms regarding concurrent government between the central government and local governments, local governments must establish Regional policies to carry out Government Affairs which become the authority of the Regions based on Standard Procedure Norms. and Criteria set by the central government.

In the regional government system as described above, there are several theories that underlie the distribution of power, including the horizontal power distribution theory and the vertical power sharing theory. According to Jimly Asshidiqie's opinion, the distribution of power which is vertical in the sense that the manifestation of power is distributed vertically down to high state institutions under the institutions that hold people's sovereignty (Juanda, 2008: 37). Meanwhile, according to Miriam Budiardjo, a vertical division of power means a division of power between several levels of government. In a Unitary State, where a unitary state is a form of state in which the highest authority is in the hands of the central government, here the central government has full power in government.

Meanwhile, regional government affairs in the forestry sector are selected governmental affairs, namely government affairs which must be carried out by the regions in accordance with the regional potentials. In Law Number 23 of 2014, the implementation of government affairs in the fields of forestry, maritime affairs, as well as energy and mineral resources is divided between the central and provincial governments. Government affairs in the forestry sector related to the management of regency / municipal forest park (TAHURA) fall under the authority of the regency / city. This is further clarified in the attachment to Law Number 23 of 2014 as revised by Law Number 9 of 2015, the authority of district / city governments in the forestry sector is only in the implementation of regency / city TAHURA management. Meanwhile the authority of the provincial government in the forestry sector, namely:

1. Implementation of forest management in forest management units, except for conservation forest management units (KPHK).

2. Implementation of management plans for forest management units except for KPHK.

3. The implementation of forest utilization in production forest areas and protection forests, including forest area utilization, non-timber forest product utilization, forest product collection, environmental service utilization except for the use of carbon storage and / or absorption.

4. Rehabilitation outside state forest areas.

5. Forest protection actors in protection forests and production forests.

6. Implementation of processing of non-timber forest products. Implementation of processing timber forest products with a production capacity of $<6000 \mathrm{~m}^{3}$ per year.

7. Implementation of forest area management with special objectives (KHDTK) for religious purposes.

8. Implementing cross-regency / municipal protection, preservation and sustainable utilization of the Grand Forest Park (TAHURA).

9. Implementation of protection of wild flora and fauna that are not protected and / or not included in the appendix (Appendix CITIES). 
10. Implementation and management of areas with important ecosystem values and buffer zones for nature reserves and conservation areas.

11. Implementation of provincial forestry extension.

12. Community empowerment in the forestry sector.

13. Implementation of cross-regency / municipal watershed management (DAS) and within regencies / municipalities within 1 provincial region.

\section{Local Government Efforts to Prevent and Eradicate Forest Destruction}

Basically, forest management falls under the authority of the government and / or local governments. Given the various regional peculiarities as well as social and environmental conditions that are closely related to forest sustainability and the interests of the wider community that require special management capabilities (Wollenberg, 2003, p. 121). Based on Law Number 41 of 1999 concerning Forestry, it is further regulated in the Forest Protection Regulation that forest protection in state forests is part of forest management which is the authority of the government and / or local governments. Because the implementation of decentralization and regional autonomy in Indonesia is believed to be able to bring community services closer, improve people's welfare and foster local democracy. Indonesia, which is Bhineka Tunggal Ika, consists of thousands of islands, hundreds of cultures and subcultures that spread throughout the archipelago. Although the central government has implemented decentralization as a consequence of political reform, decentralization and regional autonomy are seen more as a gift (generosity) from the center to share power with the regions. Not the other way around, as a necessity and the most appropriate policy choice for Indonesia, which is the most heterogeneous in terms of regional variations and local cultural diversity.

Then the role of local governments in overcoming forest destruction in the area. Because the number of cases of forest destruction is increasing from year to year. In the preamble to Law of the Republic of Indonesia Number 18 of 2013 concerning Prevention and Eradication of Forest Destruction, it explains that forest destruction, especially in the form of illegal logging, mining without permits, and plantations without permits has caused state losses, damage to socio-cultural life and the environment, as well as increasing global warming which has become a national, regional and international issue;

Forest destruction has become a crime that has an extraordinary, organized and transnational impact carried out with a sophisticated modus operandi, has threatened the survival of the community so that in the context of preventing and eradicating forest destruction effectively and providing a deterrent effect, a strong legal basis is required and that is able to guarantee. effectiveness of law enforcement.

Likewise, the role of local governments in overcoming the problem of forest and land fires can cause damage and / or pollution to the environment, both nationally and across national borders, resulting in health problems, economic losses, ecological losses, and loss to the country's reputation. In addition, forest and land fires result in economic losses in the form of loss of livelihoods for communities around the location of the fire, which originate from burning forests and land. 
The impact of forest and land fires is very detrimental to the people and state of Indonesia. On the other hand, combating forest fires by extinguishing them requires a lot of money. This is mainly due to the lack of funds and inadequate fire fighting technology that Indonesia has. Starting from the costs involved in tackling forest fires in Indonesia, it illustrates that forest fires that occur every year in Indonesia are homework that really requires hard work, so it is hoped that all parties will be involved in it, so that forest fires do not happen again. . Therefore, to prevent and overcome forest and land fires, a joint commitment between various parties is needed to carry out forest and land fire control. The control of forest and land fires must be guided by existing laws and regulations in order to run (Supriadi, 2010, p. 444-445).

Therefore, local governments are obliged to carry out prevention and eradication of all kinds of forest destruction in their respective areas. In Law Number 18 of 2013 concerning Prevention and Eradication of Forest Destruction is regulated in Article 3 which explains that the prevention and eradication of forest destruction aims to:

a. guarantee legal certainty and provide a deterrent effect for perpetrators of forest destruction;

b. ensure the existence of forests in a sustainable manner while maintaining sustainability and not destroying the environment and the surrounding ecosystem;

c. optimize the management and utilization of forest products by taking into account the balance of forest functions in order to create a prosperous community; and

d. Increasing the capacity and coordination of law enforcement officials and related parties in handling the prevention and eradication of forest destruction.

In the general explanation of Law Number 18 of 2013 concerning the Prevention and Eradication of Forest Destruction, it is clear that efforts to prevent forest destruction are carried out through policy making by the Government and local governments as well as by increasing community participation. In the context of eradicating forest destruction, this Law regulates the categories of organized forest destruction, whether direct, indirect or other related acts. In order to increase the effectiveness of eradicating forest destruction, this Law is complemented by a procedural law covering investigation, prosecution and examination in court.

The authority of the regional government in efforts to eradicate illegal logging that occurs in the area can be divided into 5 categories based on the authority of the regional government which is regulated in the relevant laws and regulations, both forestry law and regional government law. The authority of local governments in efforts to prevent and eradicate forest damage that occurs in the area is as follows: (1) Granting permits, (2) Making regional regulations, (3) Supervision, (4) Collaborating with related agencies, (5) Firm and critical in granting and revoking forest management permits (Woy, 2013: 40). In carrying out prevention and eradication of forest destruction, the regional government seeks to make policies regulating the prohibition of forest destruction and preparing concrete mitigation in terms of preventing and eradicating forest destruction, especially in the case of 
karhutla because karhutla is a disaster that occurs almost every year, especially during the dry season.

\section{Conclusion}

The conclusion in the study explains that the authority of local governments in protecting and maintaining forests in their respective areas according to Law Number 23 of 2014 as revised by Law Number 9 of 2015 concerning Regional Government, namely the regional government has the authority to regulate and limit permits for companies operating in the forestry, plantation and mining sectors in their respective regions.

Whereas the government's efforts to prevent and eradicate forest destruction in its area according to Law Number 18 of 2013 concerning Prevention and Eradication of Forest Destruction, local governments must strive to make policies and make concrete mitigation in terms of preventing and eradicating forest destruction that occurs in each of region. 


\section{References}

Achmaliadi, Restu. (2005). Keadaan Hutan Indonesia. Forest Watch Indonesia.

Bram, Deni. (2014). Politik Hukum Pengelolaan Lingkungan Hidup. Setara Press.

Hamzah, Andi. (2005). Penegakan Hukum Lingkungan. Sinar Garfika.

Juanda. (2008). Hukum Pemerintahan Daerah Pasang Surut Hubungan Kewenangan Antara DPRD dan Kepala Daerah. Alumni.

Muhjad, Hadin. (2015). Hukum Lingkungan Sebuah Pengantar Untuk Konteks Indonesia. Genta Publishing.

Nurdiansyah, Rusdi, Willy Mahasaharu Indracahaya, \& Helmi Hali. (2005). Depok Merajut Asa Membangun Kota, Depok: Pokja Wartawan Depok.

Sarundajang. (1999). Arus Balik Kekuasaan Pusat ke Dearah. Pustaka Sinar Harapan.

Supriadi. (2010). Hukum Kehutanan dan Hukum Perkebunan di Indonesia. Sinar Grafika.

Wiyono \& Isworo, 2007, Kewarganegaraan. Ganeca Exact.

Wollenberg, Eva \& Hariadi Kartodiharjo. (2003). Devolusi dan UndangUndang Kehutanan Baru Indonesia. Yayasan Obor Indonesia.

B., Jauchar. (2012). Otonomi Daerah dan Pengelolaan Sumber Daya Alam di Provinsi Kalimantan Timur (Studi Kasus Kewenangan Pengelolaan Kehutanan, Pertambangan dan Perkebunan). Jurnal Borneo Administrator, 8(1), 7-30. https://doi.org/10.24258/jba.v8i1.81

Woy, Ryfina Natalia. (2013). Kewenangan Pemerintah Daerah Dalam Upaya Pemberantasan Pembalakan Liar (Ilegal Logging). Jurnal Hukum Unsrat, I(3), 34-43. 